\title{
Allied Maritime Strategy in the Arctic in the 21st Century
}

\author{
Pauline Pic and Frédéric Lasserre
}

\section{Introduction}

The Arctic is an increasingly important area on the global stage, now attracting global interest. Observers acceding to the Arctic Council (AC) span from the much commented on China, to the UK, Singapore or the latest applicant, Estonia. International conferences about the Arctic draw together actors interested in the region from all over the world: in 2019, the latest Arctic Circle conference held in Reykjavik (the 2020 edition being cancelled because of the Covid-19 pandemic) attracted more than 2,000 participants, from more than 60 countries. ${ }^{1}$ Strategies for the Arctic region are thus gaining more and more importance, and many countrieseven located outside the Arctic Circle-have set up dedicated ones. ${ }^{2}$

Very early in the $20^{\text {th }}$ century, Sir Julian Stafford Corbett emphasised that maritime strategy should be considered from two complementary perspectives: what he coined as 'Grand strategy' on the one hand and which referred to the purpose of war; and on the other hand, what he called 'minor strategy', with more of an operational point of view. ${ }^{3}$ Corbett is especially known for having put forward the need to understand the utility of sea power even in limited war. ${ }^{4}$ Very early on, sea power appeared to be linked to economic practices, in a way that land warfare was not-which is why navies could be used to "secure trade, exercise political influence without necessarily resorting to war, and to apply sea power to sustain order at sea". ${ }^{5}$ Most Arctic strategies, whether they are published by a specific actor

1 "2019 Assembly," 2019, accessed January 7, 2021.

2 Lassi Heininen et al., Arctic Policies and Strategies-Analysis, Synthesis, and Trends, IIASA (Laxenburg, Austria, 2020).

3 Julian S. Corbett, Some Principles of maritime strategy (London: Longmans, Green and Co., 1911).

4 Barry M. Gough, "Maritime strategy: The legacies of Mahan and Corbett as philosophers of sea power," The RUSI Journal 133, No. 4 (1988).

5 Hew Strachan, "Maritime strategy and national policy," in The Direction of War: Contemporary Strategy in Historical Perspective, ed. Hew Strachan (Cambridge: Cambridge University Press, 2013), 157. 
— such as the Coast Guard or the Navy_or address several domains with a large scope, share the same priority: keeping the 'High North, Low Tension' paradigm alive. To paraphrase Corbett, 'Limited war', or rather peacekeeping, is thus a priority in the Arctic, and maritime strategies will be considered from this perspective. Our work will then be centred around the following questions: what kind of maritime challenges do we face in relation to the Arctic in the $21^{\text {st }}$ century and how can we best address them?

\section{Maritime Challenges in the Arctic: Beyond Traditional Security}

Security in international relations theory is a widely debated concept, with many different definitions. For the purpose of this chapter, we will consider traditional security as military security and non-traditional security as issues going beyond the traditional scope of the military, such as environmental security. ${ }^{6}$

\section{Traditional security: the return of great power competition in the Arctic?}

The return of great power competition in the Arctic is a recurring topic in the mainstream media. One can often read, for example, that "a new Cold War is brewing in the Arctic". ${ }^{7}$ Recent political developments might suggest that great power competition is back in the region, after a period of low tension that started even before the end of the Cold War. In 1987, when Mikhail Gorbachov pronounced his now famous Murmansk speech, he called upon Arctic nations to maintain the Arctic as a "zone of peace". ${ }^{8}$ Cooperation and multilateral dialogue became the norm and crises were relatively well weathered. Even after the Ukrainian crisis in 2014 and West-

6 Gunhild Hoogensen Gjørv et al., "Introduction: can we broaden our understanding of security in the Arctic?," in Environmental and Human Security in the Arctic, ed. Gunhild Hoogensen Gjørv et al. (London: Taylor \& Francis, 2013).

7 Neil Shea, "A thawing Arctic is heating up a new Cold War," National Geographic, August 2019.

8 Kristian Åtland, "Mikhail Gorbachev, the Murmansk Initiative, and the Desecuritization of Interstate Relations in the Arctic," Cooperation and Conflict 43, No. 3 (2008). 
ern sanctions towards Russia, cooperation remained effective. ${ }^{9}$ Dialogue was altered, but the "mosaic of cooperation" 10 that existed maintained a certain degree of dialogue. ${ }^{11}$ Hard security, being evacuated of the main regional forum - the Arctic Council—, was virtually a non-issue. ${ }^{12}$

In recent years, however, some elements might suggest the evolution of the situation. On the eve of the AC's ministerial meeting of 2019, Mike Pompeo, Secretary of State in the Trump administration made a remarked speech stating that great power competition was back in the Arctic, blaming Russia and China especially. ${ }^{13}$ Recently published US strategies also underline this change. The US Navy's (USN) strategic outlook for the Arctic, for example, reads that "there are recognized threats, opportunities, and risks in our return to an era of Great Power Competition". ${ }^{14}$ The US Coast Guard's (USCG) strategic outlook for the Arctic makes a similar assessment. ${ }^{15}$ For Lawson Brigham, former career Coast Guard officer, the USN and USCG had to align their views and strategies with the Trump administration's great power rivalry policy in the Arctic. This policy was articulated by the State and Defense departments. Both the USN and USCG were then able to argue for increased funding to carry out this more focused policy. ${ }^{16}$ It appears, however, that traditional security issues are becoming important for other actors. The Swedish Arctic strategy, published in autumn 2020, is a good example: an entire chapter of it is dedicated to security issues, whereas that was not the case in the previous strategy. ${ }^{17}$ At the launch event, the Swedish Minister of Foreign Affairs, Ann Linde, stat-

9 Juha Käpylä and Harri Mikkola, On Arctic Exceptionalism. Critical reflexions in the light of the Arctic Sunrise case and the crisis in Ukraine, FIIA Working Paper, (Helsinki: The Finnish Institute of International Affairs, 2015).

10 Oran R. Young, "Governing the Arctic: From Cold War Theater to Mosaic of Cooperation," Global Governance 11, No. 1 (2005).

11 Michael Byers, "Crises and international cooperation: an Arctic case study," International Relations 31, No. 4 (2017).

12 In the Ottawa declaration, the founding document of the Arctic Council, the question of hard security is dismissed in a footnote: "The Arctic Council should not deal with matters related to military security”. Arctic Council, Declaration on the Establishment of the Arctic Council, (Ottawa 1996).

13 Mike Pompeo, Looking North: Sharpening America's Arctic Focus (Rovaniemi, Finland, 6 May 2019).

14 US Navy, Strategic Outlook for the Arctic, 6 (Washington 2019).

15 US Coast Guard, Arctic Strategic Outlook, (Washington 2019).

16 Lawson Brigham, Personal communication (Wilson Center, Washington, 5 February 2021).

17 Government offices of Sweden, Sweden's strategy for the Arctic region, (Stockholm 2020). 
ed that this new strategy "reflects the deteriorating security environment" and while it was not a security strategy, "security was an important dimension of it". ${ }^{18}$

Beyond Arctic strategies, several signals can potentially reveal a deteriorating-or at least changing-security environment. In autumn 2020, Nordic ministers of defence signed a statement of intent on enhanced operational cooperation. ${ }^{19}$ At the signing of this trilateral agreement, the Swedish Minister of Defence, Peter Hultqvist, stated that "on the military side, we clearly see a Russian buildup in the Kola Peninsula, a troop building up in Arctic region and it includes both the Navy, Air Force and the Army", ${ }^{20}$ signalling a new level of Russian activity in the Arctic. As Danielle Cherpako puts it: "Between 2014-2020, Russia has demonstrated complex military exercises, and has invested heavily in Arctic-specific equipment, showing an ability to operate and adapt to changing conditions within an Arctic environment", ${ }^{21}$ with actions ranging from military exercises, such as the 2018 exercise on Franz Joseph Land, to mock attacks such as the one launched on the Norwegian Arctic radar installation in February 2018. Data from the SIPRI military expenditure database shows a significant increase in military expenditure by Russia at the turn of the 2010s. They estimate that in 2010 it represented about 49m \$US, culminating in 2016 with a budget of $79 \mathrm{~m} \$$ US. ${ }^{22}$ In 2019, though, their data estimates a $65 \mathrm{~m} \$ \mathrm{US}$ budget, signalling a relative decrease. However, military activity, expenditure, equipment and infrastructure remain at a lower level than they ever were during the Cold War. ${ }^{23}$

NATO and allied countries also conducted several exercises in the Arctic, such as the Trident Juncture exercise of 2018, hosted by Norway. A Cold Response exercise was planned for 2020 but had to be postponed due to the pandemic. Those are signals, among many others, that could indicate the return of Great Power competition in the Arctic, as defined by

18 H. E. Ann Linde, "Sweden's New Arctic Policy," ([Online], 16 November 2020).

19 Ministry of Defence of the Republic of Finland, Ministry of Defence of the Kingdom of Norway, and Ministry of Defence of the Kingdom of Sweden, Statement of Intent on Enhanced Operational Cooperation, (Porsangmoen 2020).

20 Atle Staalesen, "It is time to strengthen Nordic security, say ministers as they sign landmark defence deal," The Barents Observer, September 242020.

21 Danielle Cherpako, What is Russia Doing in the Arctic?, NAADSN (Peterborough, 2020), 6.

22 SIPRI, "SIPRI Military Expenditure Database," (Stockholm: Stockholm International Peace Research Institute, 2020).

23 Lincoln Edson Flake, "Russia's Security Intentions in a Melting Arctic," Military and Strategic Affairs 6, No. 1 (2014). 
Wohlforth, arising "out of a power shift in favor of a rising state dissatisfied with a status quo defended by a declining satisfied state". ${ }^{24}$ Some observers even suggest that signs point to an arms race in the Arctic, where "enduring rivalries between pairs of hostile powers [...] prompt[s] competitive acquisition of military capability". ${ }^{25}$ We would like to underline, however, that such claims have to be viewed with caution as cooperation remains the norm in the region. Arctic actors, until very recently, defined policies to ensure environmental security, and to protect and control open maritime spaces. This was not done as a reaction to another actor's actions, precisely trying to avoid any security dilemma. ${ }^{26}$

\section{A Changing Arctic Environment}

Several experts and researchers have expressed concern, for example, over new US strategies which ignore climate risks ${ }^{27}$. Those risks should not be ignored or discarded as secondary: they also have major security implications.

On the environmental side, there is overwhelming evidence that the Arctic climate is changing fast. ${ }^{28}$ From an oceanic perspective, the main consequence is the decline of sea ice, ${ }^{29}$ meaning that the Arctic Ocean is increasingly becoming an open sea. Several models show that the ocean could be completely ice-free in summer in the near future. ${ }^{30}$ This is bound to have consequences on human activities in the Arctic. For local populations, that means very important adjustments in terms of traditional livelihoods, health and food security, to name a few. At the international level,

24 William C. Wohlforth, "Unipolarity, Status Competition, and Great Power War," World Politics 61, No. 1 (2009).

25 Ron P. Smith, "The Influence of the Richardson Arms Race Model," in Lewis Fry Richardson: His Intellectual Legacy and Influence in the Social Sciences, ed. Nils Petter Gleditsch (Cham: Springer International Publishing, 2020), 25.

26 Kristian Åtland, "Interstate Relations in the Arctic: An Emerging Security Dilemma?," Comparative Strategy 33, No. 2 (2014/03/15 2014).

27 Melody Schreiber, "New US Arctic strategies ignore climate risks in focus on geopolitics, experts say," Arctic Today, 20 January 2020.

28 ACIA, Arctic Climate Impact Assessment (Cambridge: Cambridge University Press, 2005).

29 Josefino C. Comiso et al., "Accelerated decline in the Arctic sea ice cover," Geophysical Research Letters 35, No. 1 (2008).

30 James E. Overland and Muyin Wang, "When will the summer Arctic be nearly sea ice free?," Geophysical Research Letters 40, No. 10 (2013). 
it means that access to and through the Arctic will become easier, allowing the development of shipping and resource exploitation. We are far from the resource Eldorado often mentioned by the media, ${ }^{31}$ neither can we expect actual polar seaways in the near or even mid-term future. ${ }^{32}$ However, the increased accessibility of the ocean and the resulting heightened global attention on it has consequences on its strategic environment, as states want to both control these more accessible maritime areas to prevent any traffic or illegal activity (navigation, fishing, exploration, illegal traffic), and to prevent accidents and pollution.

This could have direct consequences on allied capabilities in the North as they rely on critical infrastructure to support activities and the transportation of human resources. Melting permafrost and the increased presence of drifting sea ice, due to its declining age, translate into numerous complications for infrastructure. Research shows that the changing Arctic climate could affect about 15 to $20 \%$ of the existing infrastructure by the beginning of 2059; for airports specifically, about $26 \%$ of assets are expected to experience damage. ${ }^{33}$

Another major consequence of the changing climate is the increased attention that the region is getting. Many non-Arctic states now have official Arctic strategies. They are not only getting involved in the region through their observer status in the AC, the main regional forum, but also via the funding of scientific research or the negotiation of international agreements. The International Agreement to Prevent Unregulated Fishing in the High Seas of the Central Arctic Ocean, for example, was signed by Canada, Iceland, Denmark, Norway, the US, the Russian Federation but also China, Japan, South Korea and the EU. The region is increasingly becoming a 'global region'. This growing interest from third parties can enable the development of renewed cooperation in Arctic governance, but it has also elicited a growing fear among Arctic states that newcomers, especially China or India, would position themselves as game changers, with a

31 Frédéric Lasserre and Pauline Pic, "Ressources naturelles. Une évolution contrastée face aux fortes contraintes du marché mondial," L'Année Arctique (2020).

32 Frédéric Lasserre et al., "Polar seaways? Maritime transport in the Arctic: An analysis of shipowners' intentions II," Journal of Transport Geography 57 (2016); Frédéric Lasserre and Sébastien Pelletier, "Polar super seaways? Maritime transport in the Arctic: an analysis of shipowners' intentions," Journal of Transport Geography 19, No. 6 (2011).

33 Luis Suter, Dmitry Streletskiy, and Nikolay Shiklomanov, "Assessment of the cost of climate change impacts on critical infrastructure in the circumpolar Arctic," Polar Geography 42, No. 4 (2019/10/02 2019). 
view to changing the norms of governance and asserting political ambitions in the region. ${ }^{34}$ How can NATO position itself in front of this wide array of challenges, while maintaining a political status quo where cooperation remains the norm?

\section{Managing Allied Maritime Challenges in the 21st Century Arctic}

"The importance of the Arctic is increasing for several reasons. Partly because we see more Russian presence up in the Arctic. We see also China is increasing their presence in the Arctic. [...] And, of course, the melting of the ice means also that the whole geography is going to change, because it will be easier to have economic activity, sea lines of communications and so on [...]. So this is changing the whole importance of the Arctic." 35

Those words, pronounced by Jens Stoltenberg on the occasion of a conference held for the $70^{\text {th }}$ anniversary of NATO, sum up many of the challenges for the Arctic in the $21^{\text {st }}$ century. Drastic changes in the Arctic's strategic environment and types of threat have questioned the very relevance of the organisation. And for a while, NATO was absent from the region as diplomatic activities took centre stage at the end of the Cold War. NATO's return on the Arctic stage was very low-key, with a first seminar organised in Reykjavik in 2009-probably partly as a reaction to Moscow's flag planting episode on the oceanic floor of the North Pole in $2007 .{ }^{36}$ Later on, the NATO Parliamentary Assembly discussed security in the Arctic, producing a report in $2017 .{ }^{37}$ In June 2020, Jens Stoltenberg explicitly referenced the Arctic at the launch of the NATO 2030 initiative. ${ }^{38}$ It does seem that the

34 Oran R. Young, "Is It Time for a Reset in Arctic Governance?," Sustainability 11, No. 16 (2019); Per Erik Solli, Elana Wilson Rowe and Wrenn Yennie Lindgren, "Coming into the cold: Asia's Arctic interests," Polar Geography 36, No. 4 (2013/12/01 2013).

35 Jens Stoltenberg, "NATO Engages: Innovating the Alliance - Q\&A," 3 December 2019.

36 Helga Haftendorn, "NATO and the Arctic: is the Atlantic alliance a cold war relic in a peaceful region now faced with non-military challenges?," European Security 20, No. 3 (2011).

37 NATO Parliamentary Assembly, NATO and security in the Arctic, NATO (Brussels, 2017).

38 Jens Stoltenberg, "Remarks by NATO Secretary General Jens Stoltenberg on Launching \#NATO2030 - Strengthening the Alliance in an Increasingly Competitive World", NATO (8 June 2020). 
Arctic remains on NATO's agenda, though maybe in a less visible manner. Even though there is no official NATO Arctic strategy, reflection has been focused on the alliance's operational planning and the organisation is seeking to assert its presence in the region through regular large-scale exercises, such as Trident Juncture, or the establishment of a new Joint Force Command for North Atlantic and High North operations in Norfolk, Virginia.

The Arctic cannot, however, be understood as a monolithic security region. Five of the eight Arctic states are part of NATO and don't necessarily see eye to eye on how the organisation should be involved in the region. Norway, for example, sees NATO as the cornerstone of its security, and has indeed faced an increase in Russian air military activity since 2014, as have Finland and Sweden. Canada, on the other hand, strongly resisted any involvement by the organisation in the North, or even any mention of the Arctic in official NATO documents. ${ }^{39}$ As far as non-traditional security is concerned, during the Lisbon summit, where NATO's new strategic concept was presented in 2010, climate change was briefly mentioned, without any explicit link to the Arctic, as per Canada's request. ${ }^{40}$ For EuroAtlantic security, the Arctic remains a highly strategic region. Duncan Depledge therefore argues that NATO should be more consistent in its definition of the Arctic, being present in the European High North, but should also normalise its presence in the wider Arctic to normalise and enhance alliance interest and activity in there. ${ }^{41}$

What could be underlined is that the Arctic is strategic for NATO members, especially in terms of deterrence. As Andrea Charron puts it, "The Arctic is one component of an integrated NATO deterrence posture, in conjunction with NORAD and USNORTHCOM". ${ }^{42}$ However, NATO is not central to the stability of the region. Strong cooperation remains the norm in the Arctic because the AC has been successful in fostering dialogue and peaceful cooperation between members, indigenous groups and observer states. The fact that hard security is outside its mandate has allowed discussions to remain possible even when crises were happening in

39 Andreas Østhagen, Gregory Levi Sharp and Paal Sigurd Hilde, "At Opposite Poles: Canada's and Norway's approaches to security in the Arctic," The Polar Journal 8, No. 1 (2018).

40 Haftendorn, "NATO and the Arctic: is the Atlantic alliance a cold war relic in a peaceful region now faced with non-military challenges?".

41 Duncan Depledge, "NATO and the Arctic," The RUSI Journal (2021).

42 Andrea Charron, "NATO and The Geopolitical Future of the Arctic," Arctic Yearbook (2020). 
other parts of the globe. This political status quo should remain a priority and be carefully balanced against NATO's deterrence posture.

\section{Conclusion}

The alliance has some strengths which enable it to deal with future maritime challenges in the Arctic. Its hard capabilities are essential for power projection, strategic deterrence and maritime security and presence. As underlined by NATO's secretary general, the priority of the alliance should be first and foremost to remain predictable and be present while working on avoiding any further escalation. We believe that being aware of Arctic issues and maintaining a presence while not having any formal involvement is a well-balanced position for NATO to adopt. Avoiding a security dilemma and an increase in tensions should remain the priority of the organisation.

\section{Works cited}

ACIA. Arctic Climate Impact Assessment. Cambridge: Cambridge University Press, 2005.

"2019 Assembly." 2019, accessed 7 January 2021, http://www.arcticcircle.org/assem blies/2019.

Arctic Council. Declaration on the Establishment of the Arctic Council. Ottawa, 1996.

Åtland, Kristian. "Interstate Relations in the Arctic: An Emerging Security Dilemma?". Comparative Strategy 33, No. 2 (2014/03/15 2014): 145-66.

___ "Mikhail Gorbachev, the Murmansk Initiative, and the Desecuritization of Interstate Relations in the Arctic." [In eng]. Cooperation and Conflict 43, No. 3 (2008): 289-311.

Byers, Michael. "Crises and International Cooperation: An Arctic Case Study." International Relations 31, No. 4 (2017): 375-402.

Charron, Andrea. "Nato and the Geopolitical Future of the Arctic." Arctic Yearbook (2020).

Cherpako, Danielle. What Is Russia Doing in the Arctic? NAADSN (Peterborough: 2020).

Comiso, Josefino C., Claire L. Parkinson, Robert Gersten and Larry Stock. "Accelerated Decline in the Arctic Sea Ice Cover." Geophysical Research Letters 35, No. 1 (2008).

Corbett, Julian S. Some Principles of Maritime Strategy. London: Longmans, Green and Co., 1911.

Depledge, Duncan. "Nato and the Arctic." The RUSI Journal (2021): 1-11. 
Edson Flake, Lincoln. "Russia's Security Intentions in a Melting Arctic." Military and Strategic Affairs 6, No. 1 (2014).

Gough, Barry M. "Maritime Strategy: The Legacies of Mahan and Corbett as Philosophers of Sea Power." The RUSI Journal 133, No. 4 (1988): 55-62.

Government offices of Sweden. Sweden's Strategy for the Arctic Region. Stockholm, 2020.

Haftendorn, Helga. "Nato and the Arctic: Is the Atlantic Alliance a Cold War Relic in a Peaceful Region Now Faced with Non-Military Challenges?". European Security 20, No. 3 (2011): 337-61.

Heininen, Lassi, Karen Everett, Barbora Padrtova and Anni Reissel. Arctic Policies and Strategies-Analysis, Synthesis, and Trends. IIASA (Laxenburg, Austria: 2020).

Hoogensen Gjørv, Gunhild, Dawn Bazely, Marina Goloviznina and Andrew Tanentzap. "Introduction: Can We Broaden Our Understanding of Security in the Arctic?". In Environmental and Human Security in the Arctic, edited by Gunhild Hoogensen Gjørv, Dawn Bazely, Marina Goloviznina and Andrew Tanentzap, 1-14. (London: Taylor \& Francis, 2013).

Käpylä, Juha and Harri Mikkola. On Arctic Exceptionalism. Critical Reflexions in the Light of the Arctic Sunrise Case and the Crisis in Ukraine. Fiia Working Paper. Helsinki: The Finnish Institute of International Affairs, 2015.

Lasserre, Frédéric, Leah Beveridge, Mélanie Fournier, Pierre-Louis Têtu and Linyan Huang. "Polar Seaways? Maritime Transport in the Arctic: An Analysis of Shipowners' Intentions Ii." Journal of Transport Geography 57.

Lasserre, Frédéric and Sébastien Pelletier. "Polar Super Seaways? Maritime Transport in the Arctic: An Analysis of Shipowners' Intentions." Journal of Transport Geography 19, No. 6 (2011/11/01/ 2011): 1465-73.

Lasserre, Frédéric and Pauline Pic. "Ressources Naturelles. Une Évolution Contrastée Face Aux Fortes Contraintes Du Marché Mondial." L'Année Arctique (2020): 6-13.

Linde, H. E. Ann. "Sweden's New Arctic Policy." [Online], 16 November 2020. http://www.arcticcircle.org/virtual/sweden.

Ministry of Defence of the Republic of Finland, Ministry of Defence of the Kingdom of Norway, and Ministry of Defence of the Kingdom of Sweden. Statement of Intent on Enhanced Operational Cooperation. Porsangmoen, 2020.

NATO Parliamentary Assembly. Nato and Security in the Arctic. NATO (Brussels: 2017).

Østhagen, Andreas, Gregory Levi Sharp and Paal Sigurd Hilde. "At Opposite Poles: Canada's and Norway's Approaches to Security in the Arctic." [In eng]. The Polar Journal 8, No. 1 (2018): 163-81.

Overland, James E. and Muyin Wang. "When Will the Summer Arctic Be Nearly Sea Ice Free?". Geophysical Research Letters 40, No. 10 (2013): 2097-2101.

Pompeo, Mike. Looking North: Sharpening America's Arctic Focus. (Rovaniemi, Finland: 6 May 2019).

Schreiber, Melody. "New Us Arctic Strategies Ignore Climate Risks in Focus on Geopolitics, Experts Say." Arctic Today, 20 January 2020. 
Shea, Neil. "A Thawing Arctic Is Heating up a New Cold War." National Geographic, August 2019.

SIPRI. "Sipri Military Expenditure Database." Stockholm: Stockholm International Peace Research Institute, 2020.

Smith, Ron P. "The Influence of the Richardson Arms Race Model." In Lewis Fry Richardson: His Intellectual Legacy and Influence in the Social Sciences, edited by Nils Petter Gleditsch, 25-34. Cham: Springer International Publishing, 2020.

Solli, Per Erik, Elana Wilson Rowe and Wrenn Yennie Lindgren. "Coming into the Cold: Asia's Arctic Interests." Polar Geography 36, No. 4 (2013/12/01 2013): 253 70.

Staalesen, Atle. "It Is Time to Strengthen Nordic Security, Say Ministers as They Sign Landmark Defense Deal." The Barents Observer, 24 September 2020.

Stoltenberg, Jens. "Nato Engages: Innovating the Alliance - Q\&A." 3 December 2019. https://www.nato.int/cps/en/natohq/opinions_171550.htm?selectedLocale $=$ en.

. "Remarks by Nato Secretary General Jens Stoltenberg on Launching \#Nato2030 - Strengthening the Alliance in an Increasingly Competitive World." 8 June 20202020

Strachan, Hew. "Maritime Strategy and National Policy." In The Direction of War: Contemporary Strategy in Historical Perspective, edited by Hew Strachan, 151-65. Cambridge: Cambridge University Press, 2013.

Suter, Luis, Dmitry Streletskiy and Nikolay Shiklomanov. "Assessment of the Cost of Climate Change Impacts on Critical Infrastructure in the Circumpolar Arctic." Polar Geography 42, No. 4 (2019/10/02 2019): 267-86.

US Coast Guard. Arctic Strategic Outlook. Washington, 2019.

US Navy. Strategic Outlook for the Arctic. Washington, 2019.

Wohlforth, William C. "Unipolarity, Status Competition, and Great Power War." World Politics 61, No. 1 (2009): 28-57.

Young, Oran R. "Governing the Arctic: From Cold War Theater to Mosaic of Cooperation." [In eng]. Global Governance 11, No. 1 (2005): 9-15.

-. "Is It Time for a Reset in Arctic Governance?". Sustainability 11, No. 16 (2019): 4497. 
